\title{
INVESTIGATIONS OF TEMPERATURE AND HUMIDITY CONDITIONS IN BARN IN WINTER
}

\author{
Valerii Vtoryi, Sergei Vtoryi, Roman Ylyin \\ Institute for Engineering and Environmental Problems in Agricultural Production, Russia \\ vvtoryj@yandex.ru
}

\begin{abstract}
Creation of comfortable conditions for dairy cow housing ensures maximum realisation of their productive genetic potential; the temperature and the relative (absolute) humidity of the air are of primary importance in this respect. Russian and foreign researchers have established that temperature fluctuations in the range of +10 to $+22{ }^{\circ} \mathrm{C}$ and relative air humidity in the range of 50 to $90 \%$ do not have any adverse effect on productivity of animals. According to Russian standards, the minimum inside air temperature should be from +3 ${ }^{\circ} \mathrm{C}$ to $+10{ }^{\circ} \mathrm{C}$, with the relative humidity being 40 to $85 \%$ depending on the animal housing technology. Our study showed that in winter in the barn with tied housing of dairy cows, the air temperature varied from $+3.5^{\circ} \mathrm{C}$ to $+12.3{ }^{\circ} \mathrm{C}$, with the outside air temperature being from $-4.6^{\circ} \mathrm{C}$ to $-10.5^{\circ} \mathrm{C}$. An uneven distribution of air temperature across the barn was registered, with the difference reaching 5 to $7^{\circ} \mathrm{C}$ in some cases. This indicates an uneven and insufficient thermal insulation of the premises. The absolute air humidity in the barn was 5.42 to $9.98 \mathrm{~g} \cdot \mathrm{m}^{-3}$ and was also distributed unevenly, depending on the absolute humidity of the outside air, which was 1.46 to $3.28 \mathrm{~g} \cdot \mathrm{m}^{-3}$, and the wind direction, which created additional conditions for active ventilation of the premises. To identify the conditions causing stress in animals, the Thermal Humidity Index was applied; its values were in the range of 45.6 to 57.8, with the recommended values being 65-68. So the housing conditions of cows were considered normal. The study results were used to create Excel graphical and regression models of temperature and humidity conditions and THI in the barn, depending on variation of external weather conditions, with the coefficient of determination $\mathrm{R}^{2}$ being from 0.915 to 0.969 .
\end{abstract}

Keywords: cow barn, inside climate, temperature, air humidity.

\section{Introduction}

The temperature and humidity of the environment are crucial for the life of animals. Uncomfortable housing conditions reduce their productivity and in extreme cases can lead to death.

Foreign and Russian researchers have established the range of indoor temperature and air humidity, within which lactating cows maintain their milking performance with the maximal use of their genetic potential. Air temperature from $+10{ }^{\circ} \mathrm{C}$ to $+22{ }^{\circ} \mathrm{C}$ under the relative humidity from $50 \%$ to $90 \%$ does not directly affect the productivity of animals [1].

In winter, the inside barn temperature must be maintained above $+4{ }^{\circ} \mathrm{C}$ to $+5{ }^{\circ} \mathrm{C}$, as its further decrease leads to significant loss of milk. If the milk yield obtained at a temperature of $+10{ }^{\circ} \mathrm{C}$ is $100 \%$, the average milk loss at $-5{ }^{\circ} \mathrm{C}$ will be $14 \%[2 ; 3]$.

Recommendations of the Agriculture Ministry of the Russian Federation on the technological designing of cattle farms and complexes specify the design air temperature of $+10^{\circ} \mathrm{C}$ under the relative humidity of 40 to $75 \%$ to be provided in the stalls, boxes, combined boxes, and group cages. In the system of loose housing with deep bedding and feeding in the house, the design air temperature is assumed to be $+3{ }^{\circ} \mathrm{C}$ under the relative humidity of 40 to $85 \%$ [4].

Significant inside dimensions of cattle housing premises create conditions for uneven distribution of temperature and humidity values. The aim of our study was to substantiate the regularities of inside climate development in livestock premises depending on regional and technological features of production and to model these processes.

\section{Material and methods}

Investigation results of microclimate formation processes were the experimental data measured directly on the operating dairy farm. They are the temperature and relative humidity at different points in the barn for a certain period of time according to a certain scheme (Fig. 1). External weather conditions were determined by the data from the weather station located at a distance of $26 \mathrm{~km}$ from the farm.

The study was conducted in January-March of 2017 under conditions of Leningrad Region (the Russian Federation) in a barn, $72 \mathrm{~m}$ long and $21 \mathrm{~m}$ wide, with the capacity of 200 dairy cows with tied housing. The temperature and air humidity in the barn were measured in the daytime at nine points 
located at a height of $1.4 \mathrm{~m}$ above the floor level, as shown in Fig. 1, from 11.00 to 14.00 p.m. local time. Manure was removed by a chain-and-slat conveyor twice a day and loaded into the vehicle for further utilisation. In winter ventilation is natural through the roof ridge and by infiltration of air through the openings in the structures.

It should be noted that the barn is a part of the cattle-rearing complex consisting of several linked buildings; this influences the development of special air currents and the microclimate of the premises.

For measurements, an electronic device was used (Fig. 2) consisting of an electronic sensor with current outputs of $4-20 \mathrm{~mA}$ and measuring temperature in the range from $-40{ }^{\circ} \mathrm{C}$ to $+100{ }^{\circ} \mathrm{C}$ and relative humidity - from 0 to $98 \%$ and MSD-200 archiver with 32 GB memory card that allows to archive information obtained over a substantial period of time and transfer it to the computer for analysis and Excel report generation [5; 6].

Absolute measurement error of relative humidity did not exceed $\pm 3.0 \%$, and that of air temperature $- \pm 1.0^{\circ} \mathrm{C}$.

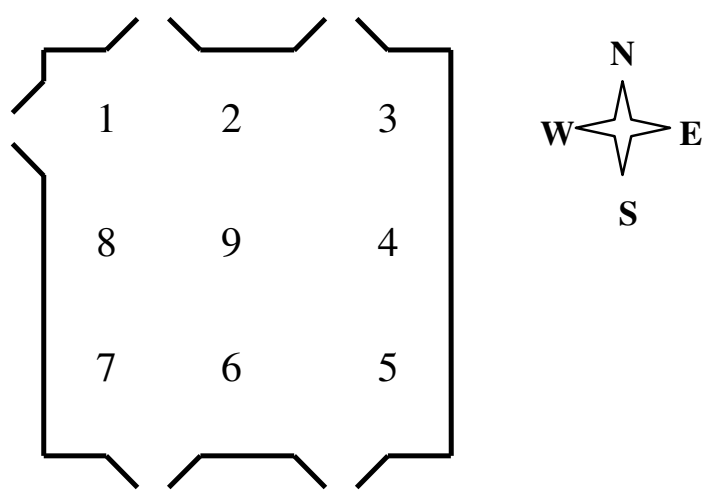

Fig. 1. Measurement points of air parameters in barn

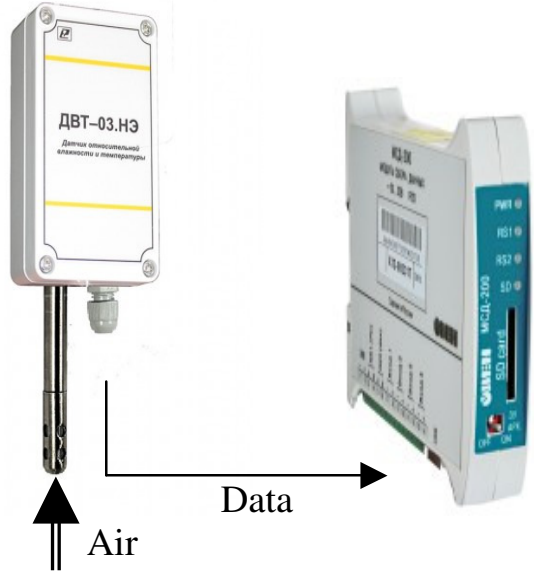

Fig. 2. Monitoring device of air parameters

\section{Results and discussion}

The study was conducted during the three coldest months; however, in 2017, the weather conditions were rather mild and the air temperature rarely dropped below $-10{ }^{\circ} \mathrm{C}$. Table 1 shows the data for the two most characteristic days with a significant difference in the parameters of the outdoor and indoor air. The average outdoor temperature during the measurement period was from $-4.6{ }^{\circ} \mathrm{C}$ to $-10.5^{\circ} \mathrm{C}$; the indoor air temperature was from $+11.8^{\circ} \mathrm{C}$ to $+7.9^{\circ} \mathrm{C}$. The relative humidity of the outdoor air was from $93.0 \%$ to $64 \%$, while the absolute air humidity (moisture content) varied from 3.28 to $1.46 \mathrm{~g} \cdot \mathrm{m}^{-3}$. The wind was of opposite directions - South-West and North-East with the speed of $2 \mathrm{~m} \cdot \mathrm{s}^{-1}$.

Table 1

Average air temperature and humidity inside and outside the barn

\begin{tabular}{|l|c|c|}
\hline \multicolumn{2}{|c|}{ Indicators } & \multicolumn{2}{c|}{ Average values of indicators } \\
\cline { 2 - 3 } & $1^{\text {st }}$ day & $2^{\text {nd }}$ day \\
\hline Air temperature, ${ }^{\mathbf{0}} \mathbf{C}:$ & -4.6 & -10.5 \\
- outside & 11.8 & 7.9 \\
- inside & & \\
\hline Relative air humidity, \%: & 93.0 & 64.0 \\
- outside & 86.0 & 81.0 \\
- inside & & \\
\hline Absolute air humidity, $\mathbf{g}^{\mathbf{2}} \mathbf{~}^{-\mathbf{3}}:$ & 3.28 & 1.46 \\
- outside & 9.21 & 5.22 \\
- inside & $\mathrm{S}-\mathrm{W} ; 2.0$ & $\mathrm{~N}-\mathrm{E} ; 2.0$ \\
\hline Wind direction and speed, $\mathbf{~} \cdot \mathbf{s}^{-\mathbf{1}}$ & \\
\hline
\end{tabular}


The data presented in Table 1 indicate the relationship between the parameters of the outdoor and indoor air. When the temperature of the outdoor air decreases, the temperature inside the barn also decreases in a certain pattern. A similar dependence exists for the humidity conditions in the animal houses. The main relevant parameter is the absolute humidity of the air, which characterises the excess of water vapor in the room in comparison with the ambient conditions.

Fig. 3 presents the monitoring results of the absolute humidity in the barn on the first and the second day, correspondingly. The graphs show that the absolute air humidity inside the room is uneven and varies significantly: on the first day - from 8.23 to $9.98 \mathrm{~g} \cdot \mathrm{m}^{-3}$, on the second day - from 5.42 to $7.68 \mathrm{~g} \cdot \mathrm{m}^{-3}$. Moreover, in absolute value, the parameters depend on the moisture content of the outdoor air and the wind direction. The wind creates additional conditions for the active ventilation of the room.

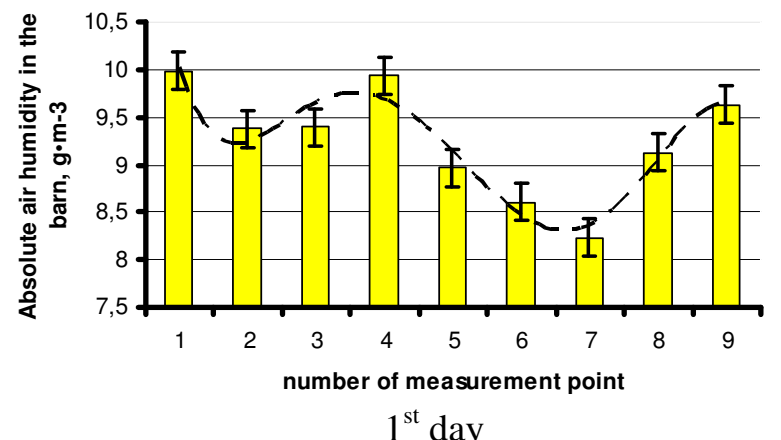

$1^{\text {st }}$ day

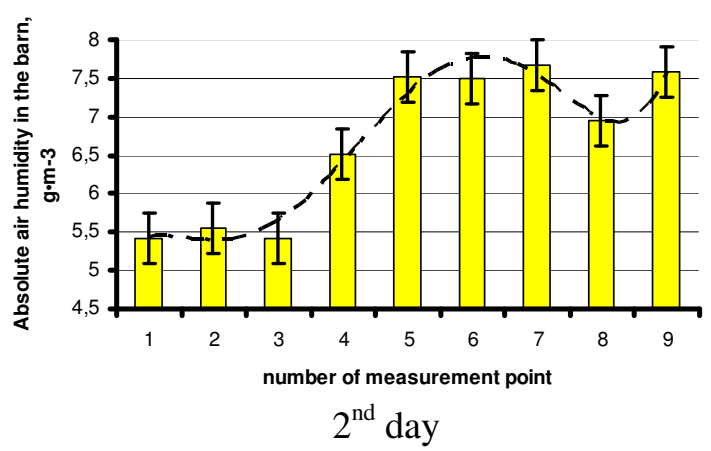

$2^{\text {nd }}$ day

Fig. 3. Graph of absolute air humidity in relevant points in barn:

$$
\text { ------ line of approximated data }
$$

The selected factor - the measurement point of microclimate parameters, is complex, since two coordinates - the length and the width measure its position on the barn area. Statistical processing of experimental data allowed creating regression models $(1,2)$ of distribution of moisture released by animals and evaporated from the wet surfaces inside the barn. Graphically the regression models are shown with a dashed line in Fig.3; the values at the measurement points are within the standard error. Coefficients of determination R2 0.921 and 0.969 indicate the close relationship between the dependent and independent variables of the model.

$$
\begin{gathered}
W_{1}=-0.0049 n^{5}+0.1292 n^{4}-1.2293 n^{3}+5.1739 n^{2}-9.4601 n+15.397 . R^{2}=0.921, \\
W_{2}=0.0035 n^{5}-0.0777 n^{4}+0.5824 n^{3}-1.7225 n^{2}+2.103 n+4.561 . R^{2}=0.969,
\end{gathered}
$$

where $W-$ absolute air humidity in the barn on the first and second day, correspondingly, $\mathrm{g} \cdot \mathrm{m}^{-3}$; $n$ - number of the measurement point;

$R^{2}$ - coefficient of determination.

Fig. 4 presents the measurement results of air temperature in the barn on the first and second day, correspondingly. The graphs show that the pattern of temperature variation in the barn is similar to that of the absolute humidity, and these parameters are interrelated. Moreover, there is a correlation with the outdoor air parameters. The indoor air temperature, dependent on the location of the measuring point, ranged from $+11.1^{\circ} \mathrm{C}$ to $+12.3^{\circ} \mathrm{C}$ on the first day. On the second day, when the temperature of the outdoor air decreased, the air temperature inside the barn also decreased, with the difference varying from $+3.5^{\circ} \mathrm{C}$ to $+10.4{ }^{\circ} \mathrm{C}$ that indicates an uneven and insufficient thermal insulation of the premises.

Based on the results of statistical processing of the study data, regression models $(3,4)$ of air temperature dependence on the location of the measurement points in the barn were created. Graphically, the regression models are shown with a dashed line in Fig. 4; the values at the measurement points are within the standard error. The coefficients of determination $R^{2} 0.915$ and 0.959 indicate a close relationship between the dependent and independent variables of the model. 

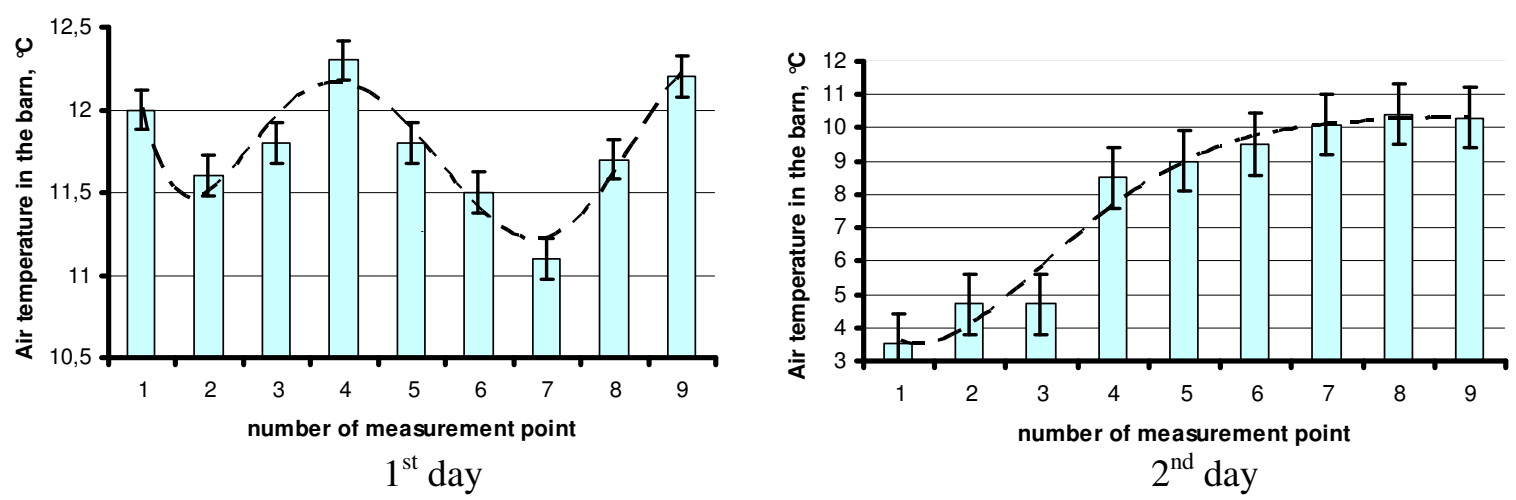

Fig. 4. Graph of air temperature in the relevant points in barn: - line of approximated data

$$
\begin{aligned}
& T_{1}=-0.0033 n^{5}+0.0896 n^{4}-0.883 n^{3}+3.8365 n^{2}-7.0793 n+16.058 . R^{2}=0.915, \\
& T_{2}=-0.0016 n^{5}+0.0501 n^{4}-0.5978 n^{3}+3.1108 n^{2}-5.3813 n+6.442 . R^{2}=0.959,
\end{aligned}
$$

where $T$-inside air temperature on the first and second day, respectfully, ${ }^{\circ} \mathrm{C}$;

$n$ - number of measurement point

$R^{2}$ - coefficient of determination.

In dairy farming, the Temperature Humidity Index (THI) is used to estimate the combined effects of environmental temperature and humidity on the cows and to reliably assess the risk of heat stress and the need of inside climate control in the barn [7].

The stress threshold is expected to initiate at THI $>75$; THI $>84$ may lead to fatal consequences. According to the study results of several scientists, the losses in milk production may occur at $\mathrm{THI}=65[8 ; 9]$. Consequently, to avoid it, the cooling of animals should start at THI $=65$.

THI was calculated for the barn under investigation. Calculation results are presented in Fig. 5. The graphs show that behaviour of THI is similar to that of temperature and humidity in the barn. The minimum THI 45.6 was observed on the second day, the maximum THI 57.8 - on the first day. On the first day, the average THI was 56.7, on the second day -50.8 that also indicates its relationship with external weather conditions.

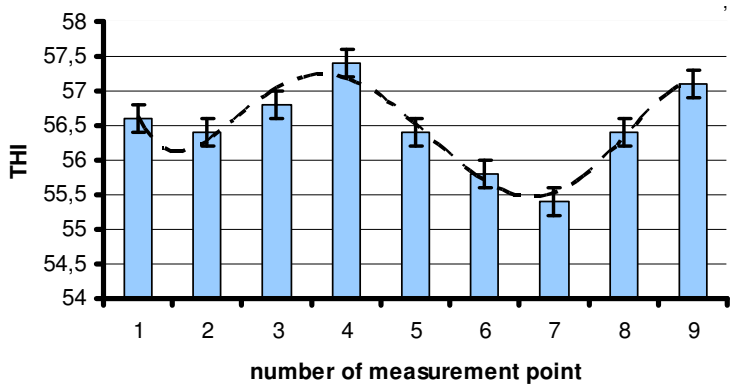

$1^{\text {st }}$ day

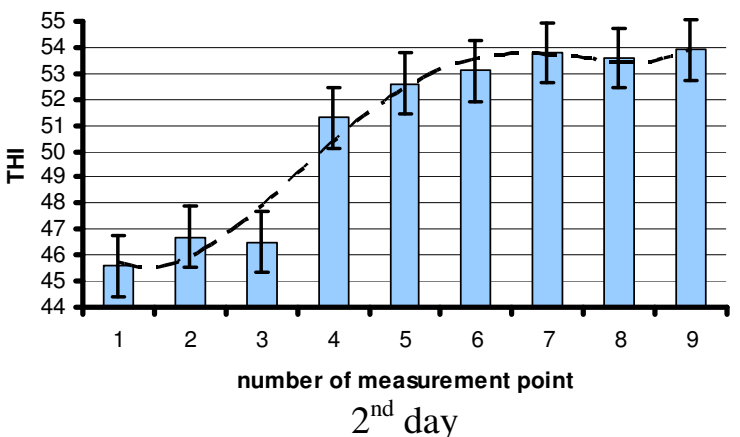

$2^{\text {nd }}$ day

Fig. 5. THI graph in relevant points in barn:

------ line of approximated data

Based on the results of statistical processing of the study data and calculations, regression models $(5,6)$ of the THI dependence on the location of the measurement points in the barn were created. Graphically, the regression models are shown with a dashed in Fig.5; the values at the measurement points are within the standard error.

$$
\begin{gathered}
I_{1}=-0.0058 n^{5}+0.1509 n^{4}-1.4233 n^{3}+5.8452 n^{2}-10.008 n+62.067 . R^{2}=0.943, \\
I_{2}=0.0009 n^{5}-0.0013 n^{4}-0.2446 n^{3}+2.2944 n^{2}-4.9882 n+48.692 R^{2}=0.962,
\end{gathered}
$$

where $I-$ THI in the first and second day, respectfully;

$n$ - number of measurement point;

$R^{2}$ - coefficient of determination. 
Coefficients of determination $R^{2} 0.943$ and 0.962 indicate a close relationship between the dependent and independent variables of the model.

\section{Conclusions}

Creating comfortable conditions for cows ensures the maximum realisation of their productive genetic potential. The main parameters in this respect are temperature and relative (absolute) air humidity. Temperature fluctuations in the range of +10 to $+22^{\circ} \mathrm{C}$ and relative air humidity in the range of 50 to $90 \%$ are favourable for the animals and do not have any adverse effect on their performance.

Our study showed that in winter in the barn with the tied housing of dairy cows, the air temperature varied from $+3.5^{\circ} \mathrm{C}$ to $+12.3{ }^{\circ} \mathrm{C}$, with the outdoor air temperature varying from $-4.6{ }^{\circ} \mathrm{C}$ to $-10.5^{\circ} \mathrm{C}$. Uneven distribution of air temperature was registered across the barn, with the difference reaching 5 to $7{ }^{\circ} \mathrm{C}$ in some cases that indicated uneven and insufficient thermal insulation of the room.

The absolute humidity in the barn was from 5.42 to $9.98 \mathrm{~g} \cdot \mathrm{m}^{-3}$; it was distributed unevenly, depending on the absolute humidity of the outdoor air, which was 1.46 to $3.28 \mathrm{~g} \cdot \mathrm{m}^{-3}$, and the wind direction, which created additional conditions for active ventilation of the premises .

The Thermal Humidity Index was used to assess the risk of heat stress of animals. In the barn under investigation, the THI was found to be from 45.6 to 57.8 , with the recommended values being 65-68 that indicated normal conditions of cow housing.

The study results were used to create Excel graphical and regression models of temperature and humidity conditions and THI in the barn, depending on variation of external weather conditions, with the coefficient of determination $\mathrm{R}^{2}$ being from 0.915 to 0.969 .

\section{References}

[1] Пчелкин Ю.Н., Сорокин А.И. Устройство и оборудование для регулирования микроклимата в животноводческих помещениях. (Device and equipment for climate control in livestock houses). М., Россельхозиздат, 1977. 216 р. (In Russian)

[2] Ковальчикова М., Ковальчик К. Адаптация и стресс при содержании сельскохозяйственных животных (Adaptation and stress under conditions of livestock housing). М. Колос, 1978. 271 p. (In Russian)

[3] Юрков В.М. Микроклимат животноводческих ферм и комплексов. (Inside climate in livestock farms and complexes). М. Россельхозиздат, 1985. 223 p. (In Russian)

[4] Методические рекомендации по технологическому проектированию ферм и комплексов крупного рогатого скота. РД-АПК 1.10.01.02-10. (Management Directive for Agro-Industrial Complex. Recommendations on technological designing of cattle farms and complexes). MCX РФ. M, 2011, 108 p. (In Russian)

[5] Valerii Vtoryi, Sergei Vtoryi, Evgenia Lantsova, Vladislav Gordeev. Effect of weather conditions on content of carbon dioxide in barns. $15^{\text {th }}$ International Scientific Coference. Engineering for rural development. Proceedings. 2016, vol. 15. pp. 437-441.

[6] Валге А.М. Использование систем Excel и Mathcad при проведении исследований по механизации сельскохозяйственного производства. (Application of Excel and Mathcad in investigations associated with mechanisation of agricultural production). СПб. ГНУ СЗНИИМЭСХ Россельхозакадемии. 2013. 200 р. (In Russian)

[7] Scientific report of EFSA. Scientific report on the effects of farming systems on dairy cow welfare and disease. Report of the Panel on Animal Health and Welfare. Annex to the EFSA Journal (2009) 1143, pp. 1-284. Available at: http://onlinelibrary.wiley.com/doi/10.2903/j.efsa.2009.1143r (Date of access 14.02.2018)

[8] Пирон О., Малинин И. Как пережить тепловой стресс и не потерять молоко (How to live through thermal stress and not to lose milk. Животноводство России. 2015. №6. pp.48-50. (In Russian)

[9] Вандани С. Уберечь корову от перегрева (Protecting cow from overheat). Животноводство России. 2017. №6. pp.34-37. 